\title{
A brief review of the risk assessment in Romania compared to Finland
}

\author{
Crina Maria Barb $^{1 *}$ \\ ${ }^{1}$ University of Petrosani, Faculty of Mines, 20 University Street, Petrosani, Romania
}

\begin{abstract}
Risk assessment is a foundation for successful management of Occupational Health and Safety, as well as an important key in order to decrease the number of work accidents. Moreover, risk assessment is an essential part of normal safety activity in work places and it includes positive factors such as: productivity, motivation and creativity. The first part of the paper focuses on a legislative background of risk assessment in Romania compared to Finland, based on the Occupational Health and Safety Act. The second part represents a comparative analysis regarding the risk assessment instruments used in Romania in comparison with those from Finland. The third part includes a current perspective regarding risk management in Finland and its impact of the situation in work life. The aim of this paper is to realize a brief review of risk assessment in Romania compared to Finland in order to take into consideration both the advantages and disadvantages regarding legislation, instruments used in the process of risk assessment in these countries.
\end{abstract}

\section{Introduction}

Risk assessment is a process that involves identifying, analyzing and estimating risk. Risk assessment can be done with varying degrees of complexity using methods from simple to complex ones. There are numerous risk assessment methods; their purpose is to help organizations in order to assess risks for protecting the employees' health.

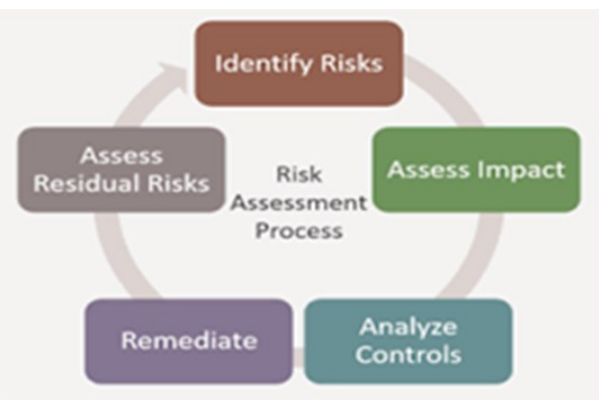

Fig. 1. The process of risk assessment

Risk assessment represents a process of estimating gravity and probability and it is lead by the top management. Organizations may use various risk assessment methods as part of their global strategy to deal with various hazards.

\footnotetext{
* Corresponding author: crina barb@yahoo.com
} 
The complexity of the occupational risk assessment method does not depend on the size of the organization, but on the dangers associated with the activities of the organization [1]. The criteria for assessing occupational hazards must be defined according to their nature and scope in order to ensure that they are used in a systematic manner [2]. The purpose of professional risk assessment is to identify risk factors and dangers within an organization. Risk assessment involves a comparison of the risk level which is calculated by analysis with the risk criteria and in some cases this risk assessment may lead to the decision to undertake more in-depth analyses.

Risk management is a rigorous process; the modern methods within it promote actions of risk prediction and anticipation, in that way amplifying the preventive function and reducing the reactive one. Effective risk management contributes to the improvement of the processes and their performance, of the activities and of the efficient use of resources.

\section{Legislative background of risk assessment in Romania compared to Finland}

In Europe, the health and safety of the workers are protected by an approach based on risk assessment. The goal of risk assessment is specified in the UE framework directive. This framework directive allows each EU member state to establish its own sanctions regime in the field of Health and Safety at work without providing provisions for limiting legal liability in case of non-compliance with its provisions [3].

In Romania, the Law on Safety and Health at work is No. 319/2006 and it is based on the European Directive 89 / 391/ CEE. The purpose of the Law 319/2006 is to introduce measures in order to promote the improvement regarding the safety and the health of employees. Besides, the law has as major goal to set general principles in terms of employees training, elimination of risk factors and prevention of occupational hazards. The procedural and normative framework regarding risk assessment in Romania does not allow a uniform approach to national risks; in this case it is necessary to complete the process on the following issues: impact assessment, aggregation of impact criteria, use of risk scenarios and probability assessment. The provisions of the Romanian legislation on risk assessment contain aspects that can be considered starting points for the implementation at national level of the risk assessment methodology.

In Finland, the Law on Occupational Safety and Health is No. $738 / 2002$ and it is based on the European Directive 89/391/CEE. The Finnish Law on Safety and Health of employees has faced psychosocial risks for many years. The Finnish law aims to eliminate the dangers regarding physical and mental health of employees and it refers particularly to the prevention of violence, harassment and reduction of workload. Law No. 738/2002 contains basic provisions and general objectives on Occupational Safety and Health. The purpose of the law is to improve the conditions and the working environment of employees in order to prevent accidents and occupational diseases. In Finland, risk assessment is a significant key in the reduction of work related accidents and, besides, it is a rigorous process of the successful management of occupational health services. A review of risk assessment in Finland will be needed if working conditions change in a significant way [3].

According to ISO 31000:2018 regarding Risk Management Standard in Finland, risk assessment contains the following steps: the first stage is risk identification, the second stage involves a risk analysis where the risk is analysed in terms of the likelihood of its production and its severity. The third stage contains a risk assessment and includes the prioritization of each risk [4]. In Finland, risk assessment can be qualitative, descriptive and quantitative compared to Romania where risk assessment can be quantitative and 
qualitative. EU member states have developed risk assessment methodologies which have been adopted by the national legislation.

The European Commission has initiated a process of creating a unique methodological framework for risk assessment which consists in developing common European policies and strategies. The European Commission supports a unitary approach to risk assessment at national level such as: a better assessment of the impact of risks and also a better understanding and a unitary treatment of risks.

\section{Advantages and disadvantages of the risk assessment instruments used in both countries}

In Romania the selection of risk assessment instruments must display the following characteristics [5]:

- the results and instruments used must be comparable;

- their use in a repeatable and detectable manner;

- providing results that allow understanding the nature of the risk;

Risk assessment instruments in Romania are selected on the basis of certain factors such as [5]:

- the type and range of risks assessed;

- availability of information;

- objectives of the study;

- the need to update the risk assessment;

Table 1. Risk assessment instruments used in Romania

\begin{tabular}{|c|c|c|c|}
\hline $\begin{array}{c}\text { Risk } \\
\text { assessment } \\
\text { instruments } \\
\text { used in } \\
\text { Romania }\end{array}$ & Description & Advantages & Disadvantages \\
\hline $\begin{array}{c}\text { INCDPM } \\
\text { METHOD [6] }\end{array}$ & $\begin{array}{l}\text { The method consists } \\
\text { in identifying all risk } \\
\text { factors at the } \\
\text { analyzed workplace } \\
\text { using pre-defined } \\
\text { control lists and } \\
\text { quantification of the } \\
\text { risk size for each } \\
\text { risk factor on the } \\
\text { basis of the } \\
\text { combination of the } \\
\text { severity and } \\
\text { frecquency of the } \\
\text { maximum possible } \\
\text { consequence. }\end{array}$ & 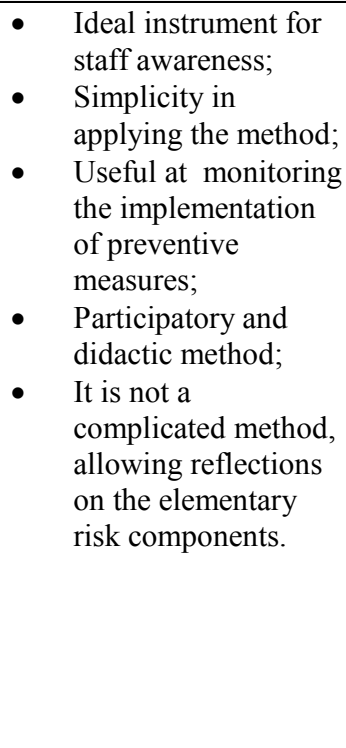 & $\begin{array}{l}\text { - A numerically- } \\
\text { expressed risk } \\
\text { assessment allows the } \\
\text { prioritization of action, } \\
\text { but it cannot take into } \\
\text { account the aspects of } \\
\text { psychological and } \\
\text { ergonomic risks; } \\
\text { Experts in the field } \\
\text { have highlighted the } \\
\text { limitations of this } \\
\text { method that they } \\
\text { consider to be } \\
\text { incomplete, unfaithful, } \\
\text { with a much too } \\
\text { pronounced subjective } \\
\text { character; they propose } \\
\text { that it be applied only } \\
\text { as a complementary } \\
\text { instrument. }\end{array}$ \\
\hline
\end{tabular}




\begin{tabular}{|c|c|c|c|}
\hline $\begin{array}{c}\text { Risk } \\
\text { assessment } \\
\text { instruments } \\
\text { used in } \\
\text { Romania }\end{array}$ & Description & Advantages & Disadvantages \\
\hline FMEA & $\begin{array}{l}\text { It is a method of risk } \\
\text { minimization and } \\
\text { analysis. The method } \\
\text { is a basic intrument } \\
\text { used in project } \\
\text { management, } \\
\text { maintenance and } \\
\text { total quality. }\end{array}$ & $\begin{array}{l}\text { It manages risks; } \\
\text { - It identifies failure } \\
\text { modes, causes and } \\
\text { effects of the system; } \\
\text { It identifies issues } \\
\text { appearing early in } \\
\text { the design process; } \\
\text { It improves means of } \\
\text { prevention; } \\
\text { It improves } \\
\text { communication } \\
\text { between customers } \\
\text { and suppliers. }\end{array}$ & $\begin{array}{l}\text { - The method can be } \\
\text { difficult to apply to } \\
\text { complex multi-layered } \\
\text { systems; } \\
\text { The studies within this } \\
\text { method can be costly } \\
\text { and time-consuming; } \\
\text { It can be used to } \\
\text { identify fault modes } \\
\text { but not combinations } \\
\text { of fault modes; } \\
\text { It establishes neither } \\
\text { protection measures } \\
\text { nor actions. }\end{array}$ \\
\hline LOPA & $\begin{array}{l}\text { The aim of this } \\
\text { method is to reduce } \\
\text { the risks and to } \\
\text { prevent dangerous } \\
\text { events. It is used in } \\
\text { risk assessment as a } \\
\text { semi-qualitative } \\
\text { method. }\end{array}$ & $\begin{array}{ll} & \text { It prevents dangerous } \\
\text { - } & \text { It rents; } \\
\text { - } & \text { It applies to } \\
\text { dangerous scenarios; } \\
\text { - It allows assessment } \\
\text { of control means; } \\
\text { It reduces risks in } \\
\text { installations to an } \\
\text { acceptable level; } \\
\text { It allows evaluation } \\
\text { of controls and their } \\
\text { efficiency. }\end{array}$ & $\begin{array}{l}\text { - It does not establish } \\
\text { protective measures for } \\
\text { the removal of the } \\
\text { consequences of a } \\
\text { possible accident; } \\
\text { It requires prior results } \\
\text { of other evaluation } \\
\text { methods; } \\
\text { It does not establish } \\
\text { protective actions for } \\
\text { the removal of the } \\
\text { consequences of a } \\
\text { possible accident. }\end{array}$ \\
\hline
\end{tabular}

In Finland, risk assessment instruments need to :

- comply with the risk assessment standards

- lead to improvements in health and safety at work

- be generalized and detailed in order to be applied at the workplace

- be simple and easy to use

Table 2. Risk assessment instruments used in Finland

\begin{tabular}{|c|c|c|c|}
\hline $\begin{array}{l}\text { Risk assessment } \\
\text { instruments used } \\
\text { in Finland }\end{array}$ & Description & Advantages & Disadvantages \\
\hline $\begin{array}{l}\text { FAULT TREE } \\
\text { ANALYSIS }\end{array}$ & $\begin{array}{l}\text { This method allows } \\
\text { the connection of } \\
\text { faults from a system } \\
\text { to a logical scheme. }\end{array}$ & $\begin{array}{l}\text { This method } \\
\text { identifies the causes } \\
\text { of system failures } \\
\text { before their } \\
\text { occurance; } \\
\text { It applies to a } \\
\text { complex system; } \\
\text { It is a quantification } \\
\text { method. }\end{array}$ & $\begin{array}{l}\text { - The quantification of } \\
\text { this method requires } \\
\text { a high level of } \\
\text { expertise; } \\
\text { - The method may be } \\
\text { time-consuming; } \\
\text { - The method analyzes } \\
\text { only a specific event. }\end{array}$ \\
\hline
\end{tabular}




\begin{tabular}{|c|c|c|c|}
\hline $\begin{array}{l}\text { Risk assessment } \\
\text { instruments used } \\
\text { in Finland }\end{array}$ & Description & Advantages & Disadvantages \\
\hline DELPHI & $\begin{array}{l}\text { This method can be } \\
\text { used to develop } \\
\text { strategies and } \\
\text { scenarios. } \\
\text { The aim of this } \\
\text { technique is to help } \\
\text { planning and } \\
\text { making decisions } \\
\text { and to facilitate } \\
\text { problem solving } \\
\text { within an } \\
\text { organization. }\end{array}$ & $\begin{array}{l}\text { It offers the } \\
\text { possibility of } \\
\text { providing } \\
\text { feedback; } \\
\text { It offers the } \\
\text { opportunity to } \\
\text { review opinions; } \\
\text { - } \quad \text { It reduces risks; } \\
\text { - } \quad \text { It is used primarily } \\
\text { as a forecasting } \\
\text { technique; } \\
\text { It is a technique } \\
\text { used within a } \\
\text { group. }\end{array}$ & $\begin{array}{l}\text { - It is not } \\
\text { recommended to use } \\
\text { this method in } \\
\text { complex situations; } \\
\text { The method is costly } \\
\text { and time-consuming; } \\
\text { - The quality of the } \\
\text { results depends on } \\
\text { the experts' } \\
\text { competence; } \\
\text { Conflicts may } \\
\text { remain unresolved in } \\
\text { certain situations. }\end{array}$ \\
\hline $\begin{array}{l}\text { HAZARD AND } \\
\text { OPERABILITY }\end{array}$ & $\begin{array}{l}\text { HAZOP is a hazard } \\
\text { identification } \\
\text { technique, and at } \\
\text { the same time a risk } \\
\text { assessment } \\
\text { instrument. }\end{array}$ & $\begin{array}{l}\text { Risk assessment } \\
\text { using this method } \\
\text { is performed by a } \\
\text { specialized team; } \\
\text { The method } \\
\text { identifies not only } \\
\text { the hazards but } \\
\text { also the operation } \\
\text { problems; } \\
\text { This method } \\
\text { includes a detailed } \\
\text { review of the } \\
\text { process; } \\
\text { The method is } \\
\text { used for technical } \\
\text { defects and human } \\
\text { errors; }\end{array}$ & 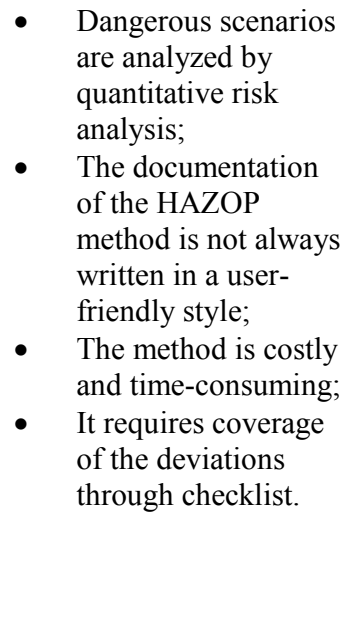 \\
\hline
\end{tabular}

In Finland risk assessment instruments are an important part of the decision-making process. There are many risk assessment instruments in Finland, worth mentioning being: bow-tie analysis, failure modes and effects analysis, hazard and operability, fault tree analysis, hazard analysis and critical control points [7]. All these risk assessment instruments are based on the principles of risk identification, analysis and assessment.

Both countries use the FMEA (Failure mode and effects analysis) method in various industries for hazard identification and risk analysis. The second method, named Fault Tree Analysis is used in both countries and it has the purpose of identifying the causes of the system failures and of determining event combinations.

\section{Risk management in Finland and its impact of the working life}

Risk management applies to a wide range of activities, processes, strategies and decisions throughout the whole life of an organization [8]. Risk management is a continuous process whose purpose is to identify potential events that affect the organization and to allow the government and organizations to reach a reasonable level of fulfilling the objectives [9]. The standard of the European Federation of Risk Management Association (FERMA) establishes a strategic process from the general objectives and aspirations of the 
organization up to identifying, evaluating and minimizating the risks within the organization.

Enterprise Risk Management (ERM) is a holistic approach to risk management; it focuses on integrating ERM into all organizational processes and into decision making.

Enterprise Risk Management can be defined as a culture of the organization and it has the goal to control the risks in an organization [9]. ERM includes the following: control of activities, risk monitoring, risk response, event identification, risk assessment, efficient communication, internal environment and setting goals.

According to the Finnish Risk Management Association, risks can be classified into four categories: strategic, operational, economic and failure risks. The emphasis on risk management is the treatment and identification of risks. There are guidelines and frameworks regarding risk management, one example being the ISO 31000 standard. The major purpose of this ISO 31000 standard is to help organizations develop a risk management strategy and develop a culture of risk management within organizations. The implementation of the ISO 31000 standard in an organization helps to increase its performance and allows for more effective decisions within it. Another important aim of this standard is to help employees become aware regarding the importance of managing and monitoring risks. Of particular importance is the safety at work of employees in Finland. Employers are responsible for familiarizing the new employees with the health and safety instructions and are compelled to act accordingly. In Finnish organizations a wide range of experts work in the field of occupational safety and health. In Finland, it is possible for adults to improve their professional skills via different types of vocational training such as: in-service training, apprenticeship training and skills testing. As far as the participation rate in vocational training is concerned, this is the most extensive form. In Finland, there are many laws, methods and regulations that improve the health and safety of employees.

Considering the importance of the professional life of employees in Finland, I have realized a SWOT analysis, the results being centralized in Table 3 .

Table 3. SWOT analysis of the professional life of employees in Finland [10]

\begin{tabular}{|c|c|}
\hline Strength & Opportunities \\
\hline $\begin{array}{l}\text { The quality of professional life in Finland } \\
\text { consists of four aspects: innovation, } \\
\text { productivity, trust and cooperation; } \\
\text { Flexibility at work requires employees to } \\
\text { feel relaxed and balanced; } \\
\text { The balance between family and } \\
\text { professional life is one of the strengths of } \\
\text { Finnish employees; } \\
\text { - The possibility of training and learning at } \\
\text { work; } \\
\text { - } \quad \text { Treating strong social relationships at work; } \\
\text { - The ability for each individual to develop } \\
\text { - } \quad \text { different skills at work; } \\
\text { - The existence of strong professional ethics; } \\
\text { - The adaption of a democratic style in } \\
\text { decision-making at work; } \\
\text { The use of working hours in a productive } \\
\text { and intelligent way; }\end{array}$ & $\begin{array}{l}\text { - } \quad \text { Developing managerial skills; } \\
\text { - } \quad \text { Low level of stress; } \\
\text { - } \quad \text { Increasing productivity; } \\
\text { A better balance between work and } \\
\text { family life; } \\
\text { - Introducing new technologies within } \\
\text { organizations; } \\
\text { - The development of professional } \\
\text { reconversion programmes; } \\
\text { Organizing workshops within } \\
\text { - } \quad \begin{array}{l}\text { Building social relationships around the } \\
\text { - }\end{array} \\
\text { Dorld; } \\
\text { facilitate the process of learning within } \\
\text { an organization. }\end{array}$ \\
\hline
\end{tabular}




\begin{tabular}{|c|c|}
\hline Weaknesses & Threats \\
\hline $\begin{array}{l}\text { - The lack of face-to-face communication } \\
\text { when the employee works from home; } \\
\text { - High labour costs; } \\
\text { - The low number of immigrants; } \\
\text { - The emergence of an isolation tendency } \\
\text { when the employee works from home. }\end{array}$ & $\begin{array}{ll}- & \text { Distraction from work tasks; } \\
\text { - } & \text { Lack of self-discipline and motivation; } \\
\text { - } & \text { Negligence of physical and mental } \\
\text { - } & \text { health; } \\
\text { - } & \text { Exergence of mental illnesses; } \\
& \text { Existence of a defective management. }\end{array}$ \\
\hline
\end{tabular}

\section{Conclusions}

Risk assessment is the foundation for effective management of the safety and health of all employees. The first part of the paper includes general theoretical aspects regarding the risk assessment process, its purpose and the role of risk assessment methods. The second part of the paper focuses on a comparison between the Romanian risk assessment legislative background and that of Finland, based on the law of safety and health at work. This part also includes some aspects related to the ISO ISO 31000:2018 Risk Management Standard.

The third part of the paper presents the advantages and disadvantages of the risk assessment instruments used in the two countries, along with a brief description of those instruments. The fourth part contains a current perspective on risk management in Finland. Moreover, a SWOT analysis has been carried out regarding professional life of employees in Finland. The overall aim of the paper was to give a short overview of the Romanian and the Finnish risk assessment, focusing on the legislative background, the risk assessment instruments and the importance of risk management.

\section{References}

1. R.I. Moraru, G.B. Băbuț, L.I., Cioca, Proceedings of the 17th International Conference - The Knowledge-Based Organization: Management and Military Sciences, pp. 735-740, Sibiu, Romania (2011)

2. R.I. Moraru, G.B. Băbuţ, L.I. Cioca, Proceedings of the 5th International Conference on Manufacturing Science and Educations - MSE 2011, Volume 2, pp. 363-366, Sibiu, Romania (2011)

3. R.I. Moraru, G.B, Băbuţ, Risk assessment - Transposition of the Directive 89/391/ CEE requirements into the laws of the European Union Member States, University of Petrosani (2009)

4. SR ISO 31000:2018 Risk Management Guidelines, https://www.iso.org/standard/65694.htm (2018)

5. M. Popescu Stelea, Integrated methodology for risk analysis and dyagnosis of Industrial Systems Safety, University of Petrosani (2015)

6. R.I. Moraru, G.B, Băbuț, Critical analysis and ways to improve the INCDPM Bucharest risk assessment method for occupational accidents and diseases, Quality - Access to Success, 14, Issue 137, pp. $113-120$

7. SR ISO 31010:2009 Risk management: Risk assessment techniques https://www.iso.org/standard/51073.html (2009)

8. SR ISO 31000:2009 Risk management: Principles and guidelines, https://www.iso.org/standard/43170.html (2009)

9. R. Kallio, Company Risk Management - Case Study, Master's Thesis, Turku University of Applied Sciences (2018)

10. T. Alasoini, J. Antila, N. Hakonen, M. Hasu, M. Yrjänäinen, M. Niemi, T. Pakarinen, E. Ramstad and H. Stålhamma, Good working life as Finland's competitiveness factor, Ministry of Economic Affairs and Employment of Finland (2016) 